Fidei: Jurnal Teologi Sistematika dan Praktika, Vol. 4, No. 2, Des. 2021

Fidei: Jurnal Teologi Sistematika dan Praktika

Terakreditasi No: 85/M/KPT/2020 (Sinta 4)

e-ISSN: $2621-8135$

http://www.stt-tawangmangu.ac.id/e-journal/index.php/fidei

Vol. 4 No.2 (Des. 2021) hlm: 245-261

p-ISSN: 2621-8151

Diterbitkan Oleh: Sekolah Tinggi Teologi Tawangmangu

\title{
Guru Pendidikan Agama Kristen Sebagai Ujung Tombak dalam Menekan Terjadinya Intolerasi di Antara Siswa di Sekolah
}

\author{
Sukardin Zebua, Talizaro Tafonao, Dewi Lidya S, Ellyzabeth \\ Sinaga, Ardianto Lahagu ${ }^{1 *}$ \\ 1) Sekolah Tinggi Teologi Real Batam, Indonesia \\ *) E-mail: sukardinzeb03@gmail.com
}

Diterima: 09 Sep. 2021 Direvisi: 25 Nov. 2021

Disetujui: 01 Des. 2021

\begin{abstract}
Abstrak
Sikap intoleransi yang ada di Indonesia saat ini telah menciptakan suatu perbedaan didalam masyarakat khususnya di antara siswa di sekolah. Dengan melihat problem tersebut maka diharapkan para guru agama Kristen mampu memberi membimbing kepada setiap siswa. Tujuan penulisan artikel ini adalah melihat sejauhmana keterlibatan para guru pendidikan agama Kristen dalam mendeteksi intoleransi diantara siswa. Metode yang digunakan penelitian adalah kulitatif deskriptif dengan kajian adalah guru Pendidikan Agama Kristen sebagai ujung tombak dalam menekan terjadinya intoleransi di antara siswa di sekolah. Hasil kajian ini adalah guru sebagai pelopor utama dalam mencintai keberagaman, mengajarkan perbedaan sebagai anugerah Tuhan, mengajarkan toleransi sebagai ajaran Tuhan Yesus. Dengan demikian salah satu cara dalam menekan terjadinya intoleransi adalah lewat pengajaran, pendampingan dan pembimbingan oleh guru-guru agama Kristen di sekolah.
\end{abstract}

Kata-Kata Kunci: Guru Kristen; Intoleransi; Keberagaman; Siswa; Rukun.

\section{Abstract}

The attitude of intolerance that exists in Indonesia today has created a difference in society, especially among students in schools. By looking at these problems, it is hoped that Christian religious teachers will be able to provide 
guidance to each student. The purpose of writing this article is to see the extent to which Christian religious education teachers are involved in detecting intolerance among students. The method used in this research is descriptive qualitative with the study being Christian Religious Education teachers as the spearhead in suppressing the occurrence of intolerance among students in schools. The results of this study are the main pioneer teachers in loving diversity, teaching difference as a gift from God, teaching tolerance as the teaching of the Lord Jesus. Thus, one way to suppress the occurrence of intolerance is through teaching, mentoring and mentoring by Christian religious teachers in schools.

Keywords: Christian Teachers; Diversity; Intolerance; Students; Pillars.

\section{Pendahuluan}

Tulisan ini membahas atau mengkaji mengenai peranan Guru Pendidikan Agama Kristen dalam menekan sikap intoleransi di antara siswa di sekolah. Sebagai negara yang besar dan memiliki penduduk terbanyak di dunia, Indonesia juga di kenal dengan negara multikultur dan juga multiagama. Karena Indonesia memiliki berbagai keberagaman maka Indonesia diikat dengan satu semboyan yaitu "Bhineka Tunggal Ika" yang berarti meskipun berbeda-beda tetapi tetap satu. Semboyan ini telah puluhan tahun menjadi kekuatan yang menyatukan bangsa Indonesia. Menurut Alpizar mengatakan bersatu dalam sebuah keberagaman dan harmoni menajadi hal yang terutama di pegang oleh setiap warga negara Indonesia. ${ }^{1}$

Sikap toleransi terhadap keberagaman menjadi hal yang harus diperhatikan dan jaga demi keutuhan sebuah bangsa dan negara. Sebelumnya penulis telah menyampaikan, bahwa Indonesia selama ini hidup dalam kedamaian dan persatuan selama bertahun-tahun. Karena sikap intoleransi dan radikalisme hampir tidak ada. Jika pun ada, itu masih pada taraf hal biasa dan tidak sulit untuk diperdamaikan. Akan tetapi tahun-tahun belakangan ini masyarakat Indonesia ada suatu perubahan yang begitu signifikan, sikap intoleransi dalam keberagaman menjadi topik yang serius dibicarakan diberbagai tempat dan media. Indonesia sedang berada pada persoalan yang serius, dimana isu-isu toleransi dan radikalisme bukan hanya saja terjadi di lingkungan masyarakat. Namun, isu-isu radikalisme dan intoleransi sudah mulai meracuni pendidikan di Indonesia. Seperti halnya yang terjadi di Bali 2014 lalu, dimana sekolah SMPN 1 Singaraja dan SMAN 2 Denpasar yang melarang

${ }^{1}$ Alpizar Alpizar, "Toleransi Terhadap Kebebasan Beragama Di Indonesia (Perspektif Islam)," TOLERANSI: Media Komunikasi Umat Bergama 7, no. 2 (2015): 132-153. 
siswanya yang beragama Islam mengenakan jilbab (hijab), dan juga kasus yang terjadi di bulan juni 2019, SD Negeri 3 Karang Tengah yang mewajibkan siswanya mengenakan seragam muslim berdasarkan surat edaran yang telah dikeluarkan. ${ }^{2}$ Bahkan ada kasus yang baru-baru ini menghebohkan publik yang terjadi di SMK Negeri 2 Padang, dimana sekolah mewajibkan siswa non muslim untuk megenakan jilbab (hijab). Berdasarkan informasi bahwa kejadian ini sudah berjalan selama 15 tahun, bahkan hal ini di atur dalam perda yang di intruksikan oleh Walikota Padang No. 451.442/BINSOS-iii/2005. ${ }^{3}$ Kasus ini menjadi perhatian semua elemen sekaligus mendapat teguran keras dari mentri Pendidikan, Nadiem Makarim. Beliau menilai bahwa aturan yang ada di SMK Negeri Padang itu sudah melanggar peraturan dan nilai-nilai Pancasila. ${ }^{4}$ Dalam penelitian yang dilakukan oleh Supriadi, Ajib dan Sugiarso mengatakan sikap intoleransi di Indonesia semakin meningkat dari 46\% sekarang menjadi 54\%.

Lanjutnya ada beberapa faktor mengapa hal ini cenderung meningkat, yakni (1) kontestasi politik, (2) ceramah yang bermuatan ujaran kebencian, (3) unggahan bermuatan ujaran kebencian di media sosial. Berdasarkan ketiga poin ini yang sering terjadi adalah ujaran kebencian melalui media sosial. ${ }^{5}$

Fenomena-fenomena yang telah diutarakan di atas adalah sebagian kecil dari kasus mengenai intoleransi di sekolah. Masih ada banyak fenomenamenomena lainnya yang perlu di ketahui. Misal seperti yang terjadi di SMAN 58 Ciracas, dimana dalam hal pemilihan ketua OSIS siswa harus memilih calon yang seiman. Bahkan yang paling miris hal ini di pelopori oleh seorang guru di sekolah itu sendiri. Melalui pesan Whatsapp dalam group menyarankan untuk tidak memilih siswa non muslim sebagai ketua OSIS. ${ }^{6}$ Sikap seperti ini adalah sikap yang tidak terpuji, sebab seharusnya seorang guru dapat menjadi teladan dan perekat toleransi, bukan menjadi pelaku intoleransi itu sendiri. Kajadiankajadian seperti ini tidak boleh dibiarkan bertumbuh dan dianggap hal biasa. Kasus-kasus seperti ini masih sering terjadi diberbagai sekolah di Indonesia seperti yang diutarakan oleh Anshari dalam tulisannya mengatakan sebagian

${ }^{2}$ Dian Ihsan, "Kumpulan Kasus Intoleransi Di Sekolah,” Kompas.Com, 2021.

${ }^{3}$ Eko Ari Wibowo, "Kasus Jilbab Di SMKN 2 Padang, P2G: Kasus Intoleransi Banyak Terjadi," Nasional.Tempo.Com.

${ }^{4}$ Mariana Fatimah Bona, "Kasus Hijab SMKN 2 Padang, Mendikbud Nilai Bentuk Intoleransi," Beritasatu.Com.

${ }^{5}$ Endang Supriadi, Ghufron Ajib, and Sugiarso Sugiarso, "Intoleransi Dan Radikalisme Agama: Konstruk LSM Tentang Program Deradikalisasi," JSW (Jurnal Sosiologi Walisongo) 4, no. 1 (2020): 53-72.

${ }^{6}$ Agung Sandy Lesmana and Ria Rizki Nirmala Sari, "Guru SMA Rasis, Bukan Jadi Teladan Malah Ajari Murid Bersikap Intoleran,” Www.Suara.Com, 2020. 
kecil pelajar di sejumlah sekolah Jawa Tengah dan Kalimantan Barat menolak ketua OSIS berbeda agama dan lebih miris lagi di kota Bandung ada 600 pelajar termasuk level SD dan SMP terpapar paham radikalisme. ${ }^{7}$ Pemerintah harus segera mengambil tindakan dalam menghentikan segala bentuk intolerasi yang tidak sesuai dengan aturan-aturan yang berlaku. Apabilah hal tersebut di biarkan, maka hal itu akan menjadi pemicu terjadinya pemecah belah bangsa ini di kemudian hari.

Berkembangnya isu-isu intoleran dan radikalisme diakibatkan karena berkembangnya ilmu pengetahuan dan teknologi (IPTEK) yang begitu cepat dan mengglobal. Sebenarnya melalui perkembangan IPTEK ini mestinya memberikan kemudahan dalam berbagai aspek kepada manusia. Seperti yang di kemukakan oleh Tafonao, masyarakat seharusnya memanfaatkan teknologi demi menambah ilmu serta menunjang aktivitas yang dilakukannya sehari-hari. ${ }^{8}$ Akan tetapi pada kenyataannya masyarakat belum siap tentang kemajuan ini, sehingga terjadi cenderungan salah dalam menggunakan media teknologi sebagai sarana dalam menyebarluaskan berita hoax, bahkan sebagai alat penipuan dan berbagai kejahatannya lainnya.

Berdasarkan kasus tersebut di atas, penulis mengamati bahwa kejadiankejadian seperti ini akan menjadi ancaman besar terhadap kemajuan bangsa Indonesia ke depan. Jika hal ini tidak ditangani dengan serius oleh pemerintah maupun lembaga pendidikan, maka besar kemungkinan Indonesia akan kehilangan generasi bangsa yang cinta akan tanah air Indonesia dan mudah terpecah belah. Bahkan juga akan berpengaruh pada aspek sosial dimana ada banyak terjadi tindakan-tindakan pelanggaran etika dan moral. ${ }^{9}$ Dan apa bila itu terus dibiarkan maka akan menimbulkan penurunanan atau kemerosotan moral dan karakter anak bangsa. Maka untuk mencegah hal itu terjadi, sangat di butuhkah semua elemen dan kelompok, baik elemen masyarakat, pemerintah, maupun lembaga pendidikan untuk mengambil andil dalam mencegah berkembangnya radikalisme dan intoleran di Indonesia khususnya di sekolah. Dengan penjelasan tentang data empiris atau kasus di atas, maka Anshari

\footnotetext{
${ }^{7}$ Moh. Anshari, "Mengawasi Perilaku Intoleransi Di Lembaga Pendidikan Monitoring Intolerant Behavior In Educational Institutions," DIDAXEI Jurnal Pendidikan 1, no. 2 (2020): 74-80.

${ }^{8}$ Talizaro Tafonao and Prasetyo Yuliyanto, "Peran Pendidikan Agama Kristen Dalam Memerangi Berita Hoaks Di Media Sosial," Jurnal Ilmiah Religiosity Entity Humanity (JIREH) 2, no. 1 (2020): 1-12.

${ }^{9}$ Asni Darmayanti Duha, “Aplikasi Konsep Ajaran Sehat Menurut2 Timotius 1:13 Oleh Guru Agama Kristen,” Fidei: Jurnal Teologi Sistematika dan Praktika 3, no. 2 (2020): 268-284.
} 
menanggapi bahwa intoleransi yang sering terjadi saat ini dalam masyarakat majemuk adalah salah satu momok yang sangat mencemaskan. ${ }^{10}$

Dengan kecemasan itu maka pada bulan Desember tahun 2016 lalu, pemerintah mencanangkan sebuah Gerakan Revolusi Mental yang di atur dalam inpres No.12 Tahun 2016. Program ini merupakan tindakan korektif terhadap karakter masyarakat Indonesia sebagai bangsa yang menuju keserasian sosial. ${ }^{11}$ Pemerintah menggulirkan gerakan ini bertujuan untuk memerbaiki dan membangun bangsa yang bermartabat, maju, makmur, modern dan sejahterah yang berdasarkan pancasila. Menurut hemat penulis gerakan ini harus di mulai dari pendidikan. Sebab, pendidikan adalah pilar utama dalam membentuk karakter dan moral anak bangsa. Hal ini juga di kemukakan oleh Kristiawan pendidikan memiliki peran yang sangat strategis dalam membentuk mental generasi anak bangsa. ${ }^{12}$ Dengan demikian pemerintah memiliki tanggung jawab dalam mendisplinkan sekolah-sekolah yang membuat aturan yang nilai-nilai Pancasila dan Undang-undang Dasar 1945.

Selain itu, guru Pendidikan Agama Kristen memiliki peran dan tanggung jawab untuk memerangi isu-isu intoleransi di sekolah. Selama ini yang menjadi korban dari tindak intoleransi itu sendiri adalah siswa Kristen. Apabila siswa Kristen menjadi pelaku daripada tindak intoleransi selama ini kemungkinan hal itu sangat kecil terjadi. Pembahasan ini tidak hanya fokus pada sekolah-sekolah Kristen tetapi kajian ini menyoroti guru-guru Kristen yang mengajar Pendidikan Agama Kristen di sekolah-sekolah swasta dan negeri, bahwa tindakan intoleransi yang dilakukan oleh siswanya tidak dibenarkan. Oleh karena itu salah satu strategi dalam menekan terjadinya konflik dan isu-isu intoleransi antara peserta didik menurut Bulkisi, dkk adalah lewat pendidikan multikultural, karena pendidikan multikultural dapat diterapkan pada semua jenis mata pelajaran dengan cara menggunakan perbedaan-perbedaan kultural yang ada pada diri siswa seperti perbedaan etnis, agama, bahasa, gender, klas sosial, ras, kemampuan, dan umur agar proses belajar menjadi lebih efektif dan mudah. Lewat cara seperti ini dapat melatih dan membangun karakter siswa untuk

${ }^{10}$ Anshari, "Mengawasi Perilaku Intoleransi Di Lembaga Pendidikan Monitoring Intolerant Behavior In Educational Institutions."

${ }^{11}$ Nainggolan Togiaratua, "Revolusi Mental Menuju Keserasian Sosial Di Indonesia," Sosio Informa 1, no. 3 (2015): 247-260.

${ }^{12}$ Muhammad Kristiawan, "Telaah Revolusi Mental Dan Pendidikan Karakter Dalam Pembentukkan Sumber Daya Manusia Indonesia Yang Pandai Dan Berakhlak Mulia," Ta'dib (Batusangkar) 18, no. 1 (2015): 13-25. 
terbiasa bersikap demokratis, humanis dan pluralis dalam lingkungan yang berbeda. ${ }^{13}$

Dengan kata lain bahwa kehadiran guru Pendidikan Agama Kristen ditengah-tengah siswa yang berbeda dapat menjembatani setiap sikap dan perilaku nagatif yang muncul di antara siswa melalui proses pembelajaran yang sedang berlangsung. Tafonao mengusulkan bahwa ada beberapa hal-hal penting yang dilakukan oleh guru Pendidikan Agama Kristen dalam menekan terjadinya intoleransi dan radikalisme di antara siswa, yaitu (1) mengajarkan hidup bersosialisasi. (2) mengajarkan sikap saling menghargai dalam perbedaan. (3) mengajarkan cara berkomunikasi. ${ }^{14}$

Guru adalah sosok yang bertanggung jawab dalam membimbing dan memotivasi anak didik dalam bersikap dan bertindak. Terlebih guru Pendidikan Agama Kristen yang tidak hanya sekedar mentransfer ilmu kepada anak didik, namun guru Pendidikan Agama Kristen juga bertanggung jawab tentang pertumbuhan kerohanian serta untuk mewariskan iman Kekristenan kepada nara didik. Guru-guru Pendidikan Agama Kristen mesti memandang dirinya sebagai seorang gembala yang bertanggung jawab akan domba-dombanya, seperti yang tertulis di dalam kitab Yohanes 21:15 dimana Tuhan Yesus memerintahkan untuk mengembalakan domba-domba-Nya. ${ }^{15}$ Jadi, guru Pendidikan Agama Kristen memiliki peranan yang sangat penting dalam menjalankan tugas yang diamanatkan oleh Tuhan Yesus. Yaitu dengan penuh kasih dan kesabaran membimbing domba-dombanya kearah yang benar menanamkan nilai-nilai kebenaran Firman Tuhan kepada anak didik, agar mencintai perdamaian dan menghargai perbedaan. Maka guru harus berusaha mengkombain kebenaran Firman Tuhan dengan nilai-nilai pancasila tanpa mengurangi inti dari sebuah kebenaran tersebut.

Berdasarkan pokok persoalan yang ada dilatar belakang, maka yang menjadi rumusan masalah dalam tulisan ini adalah apa saja upaya-upaya guru pendidikan agama Kristen dalam menekan terjadinya intoleransi di antara siswa

${ }^{13}$ Erni Bulkisi et al., Multikulturalisme Menuju Pendidikan Berbasis Multikultural, ed. Nurdin Hasan (Banda Aceh: Yayasan Anak Bangsa, 2011).

${ }^{14}$ Talizaro Tafonao, "Peran Pendidikan Agama Kristen Dalam Menjaga Kerukunan Dalam Perbedaan," in EXSEQUENDUM DIDAKTIK: Pendidikan Agama Kristen Di Sekolah, Jemaat Dan Masyarakat Plural (Serang Banten: Yayasan Pendidikan dan Sosial Indoensia Maju, 2020).

${ }^{15}$ Lilis Ermindyawati, "Peranan Guru Pendidikan Agama Kristen Terhadap Perilaku Siswa-Siswi Di SD Negeri 01 Ujung Watu Jepara," FIDEI: Jurnal Teologi Sistematika dan Praktika 2, no. 1 (2019): 40-61. 
di sekolah. Dengan melihat rumusan masalah tersebut maka tujuan penulisan artikel ini adalah melihat sejauhmana keterlibatan para guru pendidikan agama Kristen dalam mendeteksi intoleransi di antara siswa di sekolah.

Banyak penelitian yang membahas mengenai tentang intoleransi didalam lembaga pendidikan. Salah satunya adalah tulisan Anshari, yang memberikan penjelasan tentang Mengawasi Perilaku Intoleransi di Lembaga Pendidikan. Ada juga peneliti yang lain yaitu Menumbuhkan Sikap Kerukunan dalam Persepektif Iman Kristen Sebagai Upaya Deradikalisasi oleh Yonatan Alex Arifianto, yang menjelaskan bagamana cara menyikapi terjadinya intelorasi dalam umat beragama dan Elma Haryani, yang mengkaji tantang Pendidikan Moderasi Beragama Untuk Generasi Milenial: Studi Kasus 'Lone Wolf' Pada Anak Di Medan. Ketiga penelitian tersebut sama-sama menjelaskan tentang menculnya intolaransi dan radikalisme masyarakat majemuk maupun di lembaga pendidikan, tetapi kajian ini belum menjelaskan secara detail apa saja yang harus dilakukan oleh guru khususnya guru pendidikan Agama Kristen dalam menekan sejak dini terjadinya intolaransi antara siswa di sekolah. Oleh karena itu tulisan ini hadir sebagai upaya untuk melengkapi kajian para peneliti sebelumnya khususnya tentang peran guru agama Kristen dalam menyingkapi terjadinya intoleransi di antara siswa di sekolah serta memberi edukasi kepada para guru-guru pendidikan agama Kristen untuk berupaya menerapkan nilainilai Kristen yang lebih kontekstual sehingga sikap intoleransi tersebut tidak membumi di bumi pertiwi ini.

\section{Metode Penelitian}

Metode yang digunakan penelitian adalah kulitatif deskriptif. Menurut Junaidi penelitian kualitatif lebih menekankan pada kualitif atau hal terpenting. Hal terpenting yang dimaksud adalah makna di balik suatu kejadian, fenomena, dan gejala sosial yang dapat dijadikan sebagai pembelajaran berharga bagi pengembangan konsep teori. ${ }^{16}$ Penelitian ini bertujuan sejauhmana keterlibatan para Guru Pendidikan Agama Kristen dalam mendeteksi intoleransi di antara siswa di sekolah. Peneliti memeroleh data melalui studi pustaka, data empiris dan menelusuri karya ilmiah para peneliti sebelumnya yang telah dipublikasikan terkait tema kajian. Dengan menggunakan kepustakaan, peneliti mengumpulkan data melalui kajian terhadap jurnal, artikel, buku-buku dan karya ilmiah yang

${ }^{16}$ M. Djunaidi Ghony and Fauzan Almanshur, Metodologi Penelitian Kualitatif, ed. ArRuzz Media (Yogyakarta, 2012). 
resmi. Kemudian peneliti menganalisis data dan mendeskripsikan melalui teknik analisis data dengan beberapa tahan, yakni mereduksi data, menklasifikasikan dan memvervikasi data berkaitan dengan kajian terhadap artikel ini.

\section{Pembahasan dan Hasil}

Seperti yang telah penulis sampaikan di latar belakang, bahwa isu-isu anti keberagaman dan intoleransi telah masuk dan mencemari pendidikan di Indonesia. Berbagai kasus yang telah penulis paparkan di atas, memberikan sinyal bahwa pendidikan yang ada di bangsa ini sedang ada dalam bahaya. Karena apabila hal ini terus dibiarkan, maka akan berpotensi terjadinya perpecahan antara sesama anak bangsa, dan pasti bangsa Indonesia akan kehilangan generasi bangsa yang cinta akan tanah airnya. Penulis mengutip pernyataan dari Gubernur Jawa Tengah Ganjar pranowo, mengatakan bahwa intoleransi di sekolah apabila di biarkan maka akan menjadi bibit terosisme dan radikalisme. ${ }^{17}$

Sekolah merupakan lembaga pendidikan yang didalamnya mengumpulkan berbagai orang yang datang dari latar belakang yang berbeda-beda: suku, budaya, agama, ekonomi, keluarga, dan berbagai perbedaan lainnya. Tentu dengan adanya perbedaan ini tidak tertutup kemungkinan akan terjadi benturan antara sesama siswa, yang itu dapat mengarah kepada sentimen ideologi dan tertutupnya suatu kelompok. Oleh karena itu, di butuhkan adanya upaya-upaya secara sengaja dan berkelanjutan yang diarahkan untuk menyebarkan nilai-nilai toleransi di sekolah. ${ }^{18}$ Pendidikan adalah kunci atau pilar utama untuk menyebarkan nilai-nilai toleransi tersebut.

Pendidikan merupakan tempat untuk memersiapkan Sumber Daya Manusia yang berkarakter dan bertanggung jawab demi menjaga keutuhan negeri ini. Hal ini juga tertuang dalam Undang-undang No. 20 tahun 2003 tentang sisdiknas, yang bunyinya mengatakan bahwa tujuan pendidikan adalah menjadikan manusia yang beriman dan bertakwa kepada Tuhan yang Maha Esa, sehat, berilmu, berakhlak mulia, cakap, kreatif, mandiri, serta menjadi warga negara yang demokratis dan bertanggung jawab. ${ }^{19}$ Putu dalam tulisannya juga

\footnotetext{
${ }^{17}$ Feri Agus Setyawan, “Ganjar: Intoleransi Di Sekolah Bisa Jadi Bibit Radikalisme,” CNN Indonesia.

${ }^{18}$ Abdurrahman, "Membangun Sosiologi Inklusif Dalam Praktek Pembelajaran (Studi Pendidikan Toleransi Dengan Penerapan Permainan Dadu Pintar Pada Pembelajaran Sosiologi Siswa)," Jurnal Educatio 10, no. 2 (2015): 214-232.

${ }^{19}$ Inanna Inanna, "Peran Pendidikan Dalam Membangun Karakter Bangsa Yang Bermoral," JEKPEND: Jurnal Ekonomi dan Pendidikan 1, no. 1 (2018): 27-40.
} 
mengatakan bahwa pendidikan merupakan proses pewarisan budaya dan karakter terhadap generasi muda untuk meningkatkan kualitas kehidupan masyarakat dan juga bangsa di masa yang akan datang. ${ }^{20}$

Ada beberapa faktor yang menentukan keberhasilan dari suatu pendidikan, salah satunya adalah peran guru. Guru merupakan kompenen penting dalam mensukseskan pendidikan disekolah, khususnya guru Pendidikan Agama Kristen. Guru bertanggung jawab untuk menghasilkan siswa yang berkualitas, bermoral, dan berakhlak mulia. Penulis mengamati bahwa guru Pendidikan Agama Kristen memiliki peran besar dalam menjaga kerukunan di sekolah. Hal ini juga sejalan dengan apa yang di kemukakan oleh Tafonao, bahwa guru bertanggung jawab mengajarkan siswa mengenai bagaimana hidup dalam perbedaan. ${ }^{21}$ Jadi, dapat disimpulkan bahwa peran guru sangatlah penting dalam dunia pendidikan khususnya dalam menanamkan kepada anak akan cinta keberagaman. Oleh karena itu seorang guru di tuntut untuk dapat mengefektifkan proses pembelajaran yang ia lakukan baik dalam kelas maupun diluar kelas. Maka sebagai seorang pendidik sangat diharapkan memiliki pemahaman dan pengetahuan yang luas untuk mengajar anak didik dengan baik dan efektif. Guru juga harus menguasai bahan ajarnya, memiliki strategi dan metode yang menarik untuk menyampaikan materinya.

\section{Guru Pendidikan Agama Kristen menjadi pelopor utama dalam mencintai keberagaman}

Guru bertanggung jawab untuk membimbing dan mengarahkan anak didik untuk bersikap benar, baik di lingkungan sekolah maupun mayarakat. Mencintai keberagaman adalah salah satu sikap yang harus ditanamkan oleh guru kepada anak didik. Sebab anak-anak berada di lingkungan yang beragam etnis dan budaya. Anak didik setiap hari akan menghadapi banyak hal yang bertentangan dengan kehidupannya. Maka dengan itu, guru sangat perlu mengajarkan kepada anak tentang makna dari sebuah keberagaman itu sendiri. Agar anak didik tidak kaget atau terkejut apabila menemukan hal-hal yang tidak sama dengan apa

${ }^{20}$ P R Siswinarti, "Pentingnya Pendidikan Karakter Untuk Membangun Bangsa Beradab," Retrieved August, no. March (2017).

${ }^{21}$ Sri Wahyumi et al., EXSEQUENDUM DIDAKTIK: Pendidikan Agama Kristen Di Sekolah, Jemaat Dan Masyarakat Plural (Serang Banten: Yayasan Pendidikan dan Sosial Indoensia Maju, 2020). 
yang mereka miliki. Namun sebelum hal itu diajarkan sebaiknya para guru pendidikan agama Kristen pelaku dalam mencintai keberagaman itu sendiri. ${ }^{22}$

Di sekolah guru akan menemukan berbagai murid yang berbeda-beda, baik dari segi fisik, status keluarga dan banyak perbedaan lainnya. Guru di tuntut untuk tidak membeda-bedakan muridnya, kasih seorang guru kepada anak didiknya mestinya sama. Tidak boleh ada sikap hanya memerhatikan siswa tertentu. Hal-hal seperti ini harus dihindari, karena sikap ini akan menimbulkan sikap kecemburuan di antara siswa. Sebaiknya guru bersikap adil kepada seluruh siswanya, tidak menjadikan perbedaan menjadi penghambat untuk mengasihi siswanya.

Guru harus menjadi contoh dalam mencintai keberagaman dan tidak membeda-bedakan siswa dengan siswa yang lain. Dengan sikap seperti ini akan menjadi pembelajaran bagi anak didiknya. Hal ini juga sejalan dengan apa yang dikatakan oleh Karso bahwa seorang pendidik harus tampil menjadi teladan yang baik. ${ }^{23}$ Dalam penjelasan selajutnya kasro juga mengatakan bahwa guru itu di tiru dan di guguh, karena semua tingkah laku, baik dalam hal perkataan, sikap, dan perbuatan umumnya akan di ikuti atau di contoh oleh anak didiknya. $^{24}$

Berdasarkan hal itu, maka penulis membahas hal ini bahwa guru sebagai pelopor dalam mencintai sebuah perbedaan itu sendiri. Guru harus pelaku terlebih dahulu sebelum mengajarkannya kepada anak didik. Sikap mengasihi tanpa membeda-bedakan harusnya menjadi ciri khas dari seseorang guru. Karena menurut hemat penulis pengajaran yang paling efektif adalah perilaku guru itu sendiri. Firman Tuhan juga mengatakan bahwa kita adalah suratan Kristus yang terbuka (2 Kor. 3:2-3). Artinya sikap dan perilaku yang ditampilkan oleh seseorang akan menjadi pembelajaran bagi orang lain.

Guru Pendidikan Agama Kristen harus mencerminkan kasih Kristus dalam kehidupannya. Sikap guru yang menghormati sesama rekan guru dan murid akan memengaruhi cara berfikir setiap siswa, dan bukan hanya cara pandang mereka namun juga akan memengaruhi sikap dan perilaku terhadap sesama teman di sekolah. Jadi, berdasarkan semua penjelasan di atas penulis menarik

${ }^{22}$ Arozatulo Telaumbanua, "Peranan Guru Pendidikan Agama Kristen Dalam Membentuk Karakter Siswa,” FIDEI: Jurnal Teologi Sistematika dan Praktika 1, no. 2 (2018): 219-231.

${ }^{23}$ Karso, "Keteladanan Guru Dalam Proses Pendidikan Di Sekolah," Prosiding Seminar Nasional Pendidikan Program Pascasarjana Universitas PGRI Palembang, 12 Januari 20192 (2019): 382-397.

${ }^{24}$ Ibid. 
sebuah kesimpulan, bahwa guru adalah tokoh utama yang mestinya menjadi pelopor, atau pelaku utama dalam menciptakan keharmonisan dalam sebuah perbedaan.

\section{Guru Pendidikan Agama Kristen mengajarkan bahwa Perbedaan adalah Anugerah Tuhan}

Dalam perspektif iman Kristen perbedaan adalah anugerah dari Tuhan yang mestinya di syukuri dan wajib dijaga oleh semua pihak. Perbedaan merupakan kekayaan yang bernilai yang dimiliki oleh bangsa Indonesia dan mestinya itu menjadi kebanggaan tersendiri bagi negara Indonesia. Seperti yang sudah penulis sampaikan sebelumnya bahwa negara Indonesia adalah negara yang kaya akan keberagaman, berdasarkan informasi yang penulis dapatkan bahwa di Indonesia sendiri terdapat 718 bahasa ibu. ${ }^{25} \mathrm{Hal}$ ini membuktikan bahwa indonesia kaya akan perbedaan.

Fransiskus Irwan Widjaja juga mengutarakan dalam tulisannya bahwa masyarakat Indonesia memiliki berbagai latar belakang yang berbeda yang meliputi bahasa, kepercayaan, budaya, sosiologis, dan yang menarik ia mengatakan bahwa masyarakat Indonesia merupakan masyarakat yang religius dan mudah menerima suatu kebudayaan yang membawa nilai-nilai spiritual. ${ }^{26}$ Namun di balik itu semua, Indonesia memiliki beban dan tanggung jawab yang besar dalam menyatukan perbedaan-perbedaan tersebut. Hal ini juga di kemukankan oleh Ester Lina, dkk keindahan dan keberagaman ini menjadi keunggulan bagi bangsa Indonesia dalam berbangsa dan bernegara. ${ }^{27}$

Keberagaman adalah suatu keindahan yang dianugerahkan Tuhan kepada Indonesia. Patut mengucap Syukur kepada Tuhan yang luar biasa memberkati Indonesia, karena tidak semua negara seperti negara Indonesia yang kaya akan perbedaan. Maka alangkah baik dan bijaksananya apabila masyarakat memiliki kesadarna untuk saling mengormati, menghargai, bahkan saling menguatkan antara satu dengan yang lainya, agar perbedaan tidak dijadikan sebagai alat untuk memecah belah oleh orang yang tidak bertanggung jawab. Sejarah juga mengukir bahwa bangsa Indonesia ada karena perbedan yang di satukan. Maka

\footnotetext{
${ }^{25}$ Edukasi.kompas.com/read/2020/02/22/21315601/indonesia-punya-718-bahasa-ibujangan-sampai-punah?page $=$ all

${ }^{26}$ Fransiskus Irwan Widjaja, "Pluralitas Dan Tantangan Misi : Kerangka Konseptual Untuk Pendidikan Agama," Regula Fidei: Jurnal Pendidikan Agama Kristen 4, no. 1 (2019): 113.

${ }^{27}$ Ester Lina Situmorang, "Pengajaran Tuhan Yesus Mengenai Toleransi Dan Implementasinya Ditengah Masyarakat Majemuk” 4, no. 1 (2020): 88-101.
} 
dapat disimpulkan bahwa menyatunya sebuah perbedaan adalah kunci dari keberhasilan dan kemajuan sebuah negara.

Guru memiliki tanggung jawab besar bagaimana mengajarkan hal ini kepada anak didik. Anak-anak harus diberi pengertian bahwa perbedaanperbedaan yang ada itu adalah anugerah yang diberikan Tuhan atas bangsa ini, maka sebagai warga negara yang baik harus menjaga dan merawat perbedaan tersebut. Guru harus mengajarkan kepada anak-anak bagaimana mensyukuri berkat Tuhan yang begitu besar ini. Perlunya guru melatih anak didik untuk menunjukka rasa bersyukur mereka dengan bertanggung jawab atas negerinya. Mencintai perbedaan, mengasihi sesama teman sekolah adalah salah satu cara anak didik menunjukka rasa bersyukur mereka atas apa yang Tuhan telah berikan bagi mereka. Tafonao mengatakan bahwa guru Pendidikan Agama Kristen harus dengan aktif menjelaskan makna dan arti dari sebuah perbedaan. Tujuannya agar anak didik ikut serta dalam menjaganya. ${ }^{28}$ Adapun hal yang dapat di lakukan oleh guru dalam mewujudkan hal tersebut yakni menumbuhkan sikap saling menghormati antar sesama siswa. Misalnya guru Pendidikan Agama Kristen mengajarkan kepada siswa untuk menghargai temannya yang berbeda keyakinan dengan ikut serta dalam merayakan hari-hari besar keagamaan, seperti hari raya Waisak, Idul Fitri, Imlek,dan Natal.

\section{Guru Pendidikan Agama Kristen Mengajarkan Toleransi Kepada Murid Berdasarkan Ajaran Tuhan Yesus}

Sikap toleransi adalah kunci utama agar dapat hidup berdampingan di tengah-tengah masyarakat yang beragam. Pengajaran yang dilakukan oleh Tuhan Yesus mewariskan sebuah keteladanan mengenai sikap toleransi yang terdokumentasi dengan baik di dalam Alkitab. Alkitab merupakan buku penuntun bagi setiap orang dalam berfikir dan bertindak. Adapun makna dari toleransi itu sendiri merujuk kepada sikap terbuka, lapang dada, suka rela dan kelembutan terhadap orang lain yang berbeda pandangan dan keyakinan. Dalam tulisan Casram mengemukakan arti toleransi yaitu "tolerantia", memberi kelonggaran, kelembutan hati, keringanan dan kesabaran. ${ }^{29}$ Artinya toleransi merupakan sikap pengakuan dan penerimaan terhadap orang lain. Oleh karena itu, hendaknya setiap orang harus menerima orang apa adanya dengan sikap

\footnotetext{
${ }^{28}$ Wahyumi et al., EXSEQUENDUM Didakt. Pendidik. Agama Kristen Di Sekolah, Jemaat Dan Masy. Plur.

${ }^{29}$ Casram Casram, "Membangun Sikap Toleransi Beragama Dalam Masyarakat Plural," Wawasan: Jurnal Ilmiah Agama dan Sosial Budaya 1, no. 2 (2016): 187-198.
} 
yang posistif. Artinya mampu menghargai orang lain dalam rangka menggunakan hak asasinya sebagai manusia. Itu sebabnya toleransi mestinya di dukung oleh wawasan dan pengetahuan yang luas, sehingga individu dapat bersifat lebih terbuka dan mampu menghargai orang lain.

Alkitab banyak menguraikan ajaran Tuhan Yesus mengenai toleransi. Dengan tegas dan lugasnya Tuhan Yesus menyampaikan ajara-Nya kepada setiap orang. Kitab Injil mencatat bahwa salah satu materi yang diajarkan oleh Tuhan Yesus adalah mengasihi sesama. Dalam pengajaran-Nya Tuhan Yesus menempatkan manusia sebagai sesama yang harus di pandang dan diperlakukan dengan tidak melihat latar belakang agama, suku dan ras dengan dilandaskan pada kasih (Mat. 22:39). Yesus dengan tegas mengatakan bahwa semua orang adalah sama, maka harus dikasihi seperti mengasihi diri sendiri. Dengan kata lain, bahwa apa pun agama dan keyakinannya itulah saudara yang harus dihormati dan dikasihi. Karena semua orang memiliki nilai yang sama di mata Tuhan. Oleh karena itu, guru harus menanamkan nilai kebenaran ini kepada anak didik. Sikap seperti ini harus menjadi cerminan dan gaya hidup semua anak didik. Maka untuk mengaktualisasikan itu guru harus sungguh-sungguh untuk mengajar anak didik, dengan baik tentang toleransi berdasarkan ajaran Tuhan Yesus.

Perintah Tuhan Yesus untuk mengasih sesama seperti mengasihi diri sendiri adalah sikap tertinggi dalam bertoleransi. Seperti yang telah penulis sampaikan diatas bahwa semua orang adalah sama, maka wajib untuk dikasihi, dihormati diperhatikan serta di tolong dengan tulus tanpa memandang latar belakang seseorang. Dalam injil Matius termuat pernyataan Tuhan Yesus yang mengatakan bahwa segala sesuatu yang kamu kehendaki supaya orang perbuat kepadamu, perbuatlah juga kepada mereka. Itulah seluruh isi hukum taurat dan kita para nabi (Mat. 7:12). Menerima dan mengasihi setiap orang merupakan pokok pengajaran Tuhan Yesus yang wajib di hidupi oleh setiap anak didik termaksud guru.

Yesus sebagai guru Agung pernah hidup di masyarakat yang intoleran dan bersifat eksklusif. Yesus kerapkali mengalami penolakan dari pihak orang Yahudi, karena pengajaran Tuhan Yesus sangat berbanding terbalik lurus dengan ajaran para rabi-rabi Yahudi pada saat itu. Orang Yahudi yang pada dasarnya memiliki sikap yang tertutup dengan suku diluar mereka seketika runtuh oleh kehadiran Tuhan Yesus. Penerimaan Yesus terhadap wanita samaria merupakan bentuk pengajaran yang di praktekkan langsung oleh Tuhan Yesus bahwa orang yang diluar suku Yahudi juga merupakan sesama yang perlu untuk 
di perhatikan. Tembok tebal aksi intoleransi orang Yahudi runtuh pada saat Tuhan Yesus menerima dan tidak menghukum perempuan Samaria yang kedapatan berbuat dosa itu. Dengan kata lain bahwa Tuhan Yesus ini memberi pesan penting bahwa tidak pernah menyetujui aksi intoleransi. Karena bagi-Nya semua orang memiliki kedudukan yang sama. Dari kisah wanita Samaria ini memberi informasi bahwa tidak ada suku bangsa, ras kelompok tertentu, dan agama tertentu yang lebih rendah dari yang lainnya. Seperti halnya Yesus menerima keberadaan bangsa-bangsa lain dan mau bergaul dengan mereka, bahka tidak hanya itu saja Yesus juga tidak segan-segan mengambil perumpaman atau contoh yang baik dari orang-orang di luar Yahudi. ${ }^{30}$

Tuhan Yesus telah mengajar dan mempraktekkan mengenai hidup mengampuni, merangkul, menghormati dan mencintai perbedaan. Prinsipprinsip seperti ini sebainya para guru pendidikan agama Kristen juga harus bertindak seperti Yesus beritndak. Guru harus menciptakan suasana harmonis antara sesama siswa. Lingkungan sekolah menjadi tempat bagi siswa untuk mempraktekkan sikap saling mengasihi. Semua siswa diberi pemahaman bahwa bergaul kepada orang lain sangat penting, agar siswa tidak mengabaikan sisi hidup saling bertergantungan kepada yang lain, bahwa hidup ini tidak hidup dengan sendirian.

\section{Guru Pendidikan Agama Kristen Mengajarkan Hidup Rukun di Tengah- Tengah Keanekaragaman}

Hidup rukun dalam kehidupan bersosial di tengah-tengah keberagaman adalah sesuatu keadaan yang selalu didambakan dan diharapkan oleh setiap orang. Perjuangan yang telah dibangun oleh para pahlawan Indonesia mensyaratkan bahwa perjuangan tersebut perlu dibangun melalui kesatuan dalam ikatan kekeluargaan. Indonesia ada bukan kerena satu orang tetapi karena kesatuan bersama. Hal ini juga dikemukakan oleh Irene, dkk bahwa negara Indonesia dibangun diatas keaneka ragam suku, budaya, agama, etnik, dan juga bahasa. ${ }^{31}$ Dalam membangun sebuah kerukunan di masyarakat yang multikultural sangat diperlukan kesepakatan antara sesama masyarakat yang ada di suatu negara atau daerah tertentu. Oleh karena itu lingkungan sekolah atau lembaga pendidikan menjadi tempat bagi siswa untuk membangun

${ }^{30}$ Yushak Soesilo, "Gereja Dan Pluralisme Agama Dalam Konteks Di Indonesia," Jurnal Antusias 1, no. 2 (2011): 81-93.

${ }^{31}$ Irene Ludji and Mariska Lauterboom, "Learning From The Socio-Religious Integration In Solor Village Indonesia,” Analisa 22, no. 1 (2015): 43-58. 
kebersamaan. Dengan kata lain kerja sama antara semua pihak merupakan hal penting diberi ruang semua pihak termasuk guru-guru di sekolah.

Berdasarkan penjelasan tersebut di atas, maka dibutuhkan peran guru dalam mengedukasi anak didik untuk memahami hidup rukun. Meskipun berada di suatu lingkungan yang memiliki banyak keberagaman. Murid harus diajar dan dibimbing untuk selalu bersikap baik, sopan, ramah kepada semua kalangan. Guru harus berusaha sedemikian rupa untuk menumbuhkan kesadaran bagi anak didik bahwa negara Indonesia adalah negara majemuk. Artinya hidup saling menolong merupakan kunci utama dalam keberagaman tanpa memandang agama, status sosial, etnis dan bahasa. ${ }^{32}$

Salah satu contoh penting dalam mewujudkan hidup rukun yang selalu diajarkan dan dilakukan oleh siswa antara lain bermain dengan teman yang berbeda suku, membangun kerjasama, peduli dan menolong teman yang membutuhkan pertolongan dan menjauhi perselisihan di antara setiap siswa. Kitab Mazmur mengisahkan bahwa sungguh, alangkah baiknya dan indahnya, apabila saudara-saudara diam bersama dengan rukun (Maz. 133:1).

\section{Simpulan}

Berdasarkan semua penjelasan di atas, maka penulis dapat menarik sebuah kesimpulan bahwa, guru Pendidikan agama Kristen memiliki peranan yang sangat penting dalam menekan intoleransi di antara siswa. Guru agama Kristen bertanggung jawab untuk menanamkan nilai-nilai toleransi kepada seluruh anak didik. Sebab sikap toleransi terhadap keberagaman merupakan pilar utama dalam menjaga keutuhan negara Indonesia. Guru merupakan pelopor atau pelaku utama dalam mencintai perbedaan. Itu sebabnya guru harus menampilkan gaya hidup yang dapat di teladani oleh siswanya. Sikap adil dan mengasihi tanpa membeda-bedakan siswa harus menjadi indikator dari kehidupan setiap guru. Guru mengedukasi kepada murid bahwa perbedaanperbedaan yang ada adalah anugerah dari Tuhan yang wajib dijaga dan di rawat oleh setiap masyarakat Indonesia. Pengajaran-pengajaran yang disampaikan oleh guru Pendidikan Agama Kristen harus dilandaskan atas kebenaran Firman Tuhan, serta belajar dari sosok pribadi Tuhan Yesus selama Ia hidup di bumi, Sikap megasihi, sikap mengampuni, sikap tidak membeda-bedakan merupakan gaya hidup Tuhan Yesus yang harus di teladani dan diikuti oleh setiap guru

${ }^{32}$ S Widiyono, "Peran Guru Dalam Mengimplementasikan Pendidikan Multikultural," Jurnal Elementary 5, no. 2 (2018): 282-290. 
pendidikan agama Krsiten. Hidup rukun ditengah-tengah keberagaman adalah sikap yang juga harus di miliki oleh setiap siswa. Itu sebanya siswa diajar untuk bisa hidup berdampingan dengan orang lain.

\section{Daftar Pustaka}

Abdurrahman. "Membangun Sosiologi Inklusif Dalam Praktek Pembelajaran (Studi Pendidikan Toleransi Dengan Penerapan Permainan Dadu Pintar Pada Pembelajaran Sosiologi Siswa)." Jurnal Educatio 10, no. 2 (2015): 214-232.

Alpizar, Alpizar. "Toleransi Terhadap Kebebasan Beragama Di Indonesia (Perspektif Islam).” TOLERANSI: Media Komunikasi Umat Bergama 7, no. 2 (2015): 132-153.

Anshari, Moh. "Mengawasi Perilaku Intoleransi Di Lembaga Pendidikan Monitoring Intolerant Behavior In Educational Institutions." DIDAXEI Jurnal Pendidikan 1, no. 2 (2020): 74-80.

Bona, Mariana Fatimah. "Kasus Hijab SMKN 2 Padang, Mendikbud Nilai Bentuk Intoleransi." Beritasatu.Com.

Bulkisi, Erni, Eli Nurliza, Erlawana, Farizal Hadi, Hammaddin, Hizqil Apandi, Ismail, et al. Multikulturalisme Menuju Pendidikan Berbasis Multikultural. Edited by Nurdin Hasan. Banda Aceh: Yayasan Anak Bangsa, 2011.

Casram, Casram. "Membangun Sikap Toleransi Beragama Dalam Masyarakat Plural." Wawasan: Jurnal Ilmiah Agama dan Sosial Budaya 1, no. 2 (2016): 187-198.

Duha, Asni Darmayanti. “Aplikasi Konsep Ajaran Sehat Menurut2 Timotius 1:13 Oleh Guru Agama Kristen." Fidei: Jurnal Teologi Sistematika dan Praktika 3, no. 2 (2020): 268-284.

Ermindyawati, Lilis. "Peranan Guru Pendidikan Agama Kristen Terhadap Perilaku Siswa-Siswi Di SD Negeri 01 Ujung Watu Jepara." FIDEI: Jurnal Teologi Sistematika dan Praktika 2, no. 1 (2019): 40-61.

Ghony, M. Djunaidi, and Fauzan Almanshur. Metodologi Penelitian Kualitatif. Edited by Ar-Ruzz Media. Yogyakarta, 2012.

Ihsan, Dian. "Kumpulan Kasus Intoleransi Di Sekolah.” Kompas.Com, 2021.

Inanna, Inanna. "Peran Pendidikan Dalam Membangun Karakter Bangsa Yang Bermoral." JEKPEND: Jurnal Ekonomi dan Pendidikan 1, no. 1 (2018): $27-40$.

Karso. "Keteladanan Guru Dalam Proses Pendidikan Di Sekolah.” Prosiding Seminar Nasional Pendidikan Program Pascasarjana Universitas PGRI Palembang, 12 Januari 20192 (2019): 382-397.

Kristiawan, Muhammad. "Telaah Revolusi Mental Dan Pendidikan Karakter Dalam Pembentukkan Sumber Daya Manusia Indonesia Yang Pandai Dan Berakhlak Mulia." Ta'dib (Batusangkar) 18, no. 1 (2015): 13-25. 
Lesmana, Agung Sandy, and Ria Rizki Nirmala Sari. "Guru SMA Rasis, Bukan Jadi Teladan Malah Ajari Murid Bersikap Intoleran." Www.Suara.Com, 2020.

Ludji, Irene, and Mariska Lauterboom. "Learning From The Socio-Religious Integration In Solor Village Indonesia." Analisa 22, no. 1 (2015): 43-58.

Setyawan, Feri Agus. "Ganjar: Intoleransi Di Sekolah Bisa Jadi Bibit Radikalisme." CNN Indonesia.

Siswinarti, P R. "Pentingnya Pendidikan Karakter Untuk Membangun Bangsa Beradab." Retrieved August, no. March (2017).

Situmorang, Ester Lina. "Pengajaran Tuhan Yesus Mengenai Toleransi Dan Implementasinya Ditengah Masyarakat Majemuk" 4, no. 1 (2020): 88-101.

Soesilo, Yushak. "Gereja Dan Pluralisme Agama Dalam Konteks Di Indonesia." Jurnal Antusias 1, no. 2 (2011): 81-93.

Supriadi, Endang, Ghufron Ajib, and Sugiarso Sugiarso. "Intoleransi Dan Radikalisme Agama: Konstruk LSM Tentang Program Deradikalisasi." JSW (Jurnal Sosiologi Walisongo) 4, no. 1 (2020): 53-72.

Tafonao, Talizaro. "Peran Pendidikan Agama Kristen Dalam Menjaga Kerukunan Dalam Perbedaan." In Exsequendum Didaktik: Pendidikan Agama Kristen Di Sekolah, Jemaat Dan Masyarakat Plural. Serang Banten: Yayasan Pendidikan dan Sosial Indoensia Maju, 2020.

Tafonao, Talizaro, and Prasetyo Yuliyanto. "Peran Pendidikan Agama Kristen Dalam Memerangi Berita Hoaks Di Media Sosial." Jurnal Ilmiah Religiosity Entity Humanity (JIREH) 2, no. 1 (2020): 1-12.

Telaumbanua, Arozatulo. "Peranan Guru Pendidikan Agama Kristen Dalam Membentuk Karakter Siswa." FIDEI: Jurnal Teologi Sistematika dan Praktika 1, no. 2 (2018): 219-231.

Togiaratua, Nainggolan. "Revolusi Mental Menuju Keserasian Sosial Di Indonesia." Sosio Informa 1, no. 3 (2015): 247-260.

Wahyumi, Sri, Arie Rissing Natalia, Daud Darmadi, Rosnila Hura, Yusak Noven Susanto, Elsye Ribkah Runkat, Markus Oci, et al. Exsequendum Didaktik: Pendidikan Agama Kristen Di Sekolah, Jemaat Dan Masyarakat Plural. Serang Banten: Yayasan Pendidikan dan Sosial Indoensia Maju, 2020.

Wibowo, Eko Ari. "Kasus Jilbab Di SMKN 2 Padang, P2G: Kasus Intoleransi Banyak Terjadi." Nasional.Tempo.Com.

Widiyono, S. "Peran Guru Dalam Mengimplementasikan Pendidikan Multikultural." Jurnal Elementary 5, no. 2 (2018): 282-290.

Widjaja, Fransiskus Irwan. "Pluralitas Dan Tantangan Misi: Kerangka Konseptual Untuk Pendidikan Agama." Regula Fidei: Jurnal Pendidikan Agama Kristen 4, no. 1 (2019): 1-13. 